\title{
Price Convergence under EMU? First Estimates
}

\author{
Matthias Lutz \\ Institute of Economics \\ University of St. Gallen \\ Dufourstrasse 48 \\ 9000 St. Gallen \\ Switzerland \\ Tel. +41712242303 \\ Fax +41712242646 \\ matthias.lutz@unisg.ch
}

First version: June 2002

This version: December 18, 2002

\begin{abstract}
This paper examines whether European monetary union has lowered the degree of price dispersion among member countries. A number of different estimation methods are applied to four independent datasets containing prices of identical goods. While the results reported in the paper vary somewhat across goods, they provide little overall support of the European Commission's claim that the single currency would significantly deepen market integration among the euro-zone countries. Even though this should be viewed as preliminary evidence, it does suggest that there are other, more important impediments to market integration in the EU.
\end{abstract}

\section{JEL classifications: F15, F33, F36}

Acknowledgments: For comments and suggestions I would like to thank Lars Feld, Jacques Melitz and seminar participants at the 2002 Annual Conference of the Money, Macro and Finance Research Group at Warwick University and the 8th World Congress of the International Economic Organisation in Lisbon. 


\section{Introduction}

Does a common currency lead to greater market integration? Certainly European policy-makers seemed to be convinced when they set out on the Maastricht agenda to create the economic and monetary union (EMU). Despite considerable scepticism throughout the first two stages, the third and final stage of monetary union started successfully in 1999, when the exchange rates of the participating countries were permanently fixed against the euro. This paper examines to what extent price differences in the euro-zone have been narrowed by the introduction of the single currency: has 'one money' really supported the creation of 'one market'?

The empirical analysis is based on four different sets of final goods prices: (i) Big Mac prices; (ii) the cover prices of The Economist; (iii) the prices of cars; and (iv) the prices of a range of goods and services from a publication by UBS, the Swiss commercial bank (formerly Union Bank of Switzerland). Estimating the single currency effect on price dispersion suffers from a problem afflicting most studies that attempt to evaluate the effects of economic policies: we do not have an observable counterfactual. A number of methodologies have been suggested in the literature, of which three are applied here: the before-after approach, the cross-sectional approach and the difference-in-differences approach.

The results of this study suggest that the common currency has had little impact on price convergence so far. Altogether, the paper reports 519 estimates of the single currency effect, which differ in terms of price series, estimator and control group. Even though 103 of them provide statistically significant evidence that the single currency has reduced the degree of price dispersion among the member countries, there are another 64 test results with a statistically significant positive effect on price dispersion. There are some differences across datasets and specifications, but there are few price series where the gap seems to have narrowed across most test specifications.

Several possible interpretations are offered. The preferred explanation is that there are likely to be many other influences on price dispersion, such as lack of 
competition between firms, transaction costs and informational asymmetries. Even if a single currency could lower transaction costs in principle, this effect may be too small or too slow to show up in the estimates, given these other impediments to price convergence.

The structure of the paper is as follows. The next section provides an overview of the issues related to common currencies and market integration, followed by discussion of methodology and estimation methods. The fourth section describes the four datasets on prices in more detail. The estimates of the single currency effect on price differences are presented in section five. Section six concludes the paper.

\section{Common currencies and market integration: the issues}

During the past four decades the member countries of the EU have adopted a range of measures to raise the level of economic integration, culminating in the creation of the European single market in 1993. Nevertheless, prices for identical goods have stubbornly refused to converge between member countries and have repeatedly been highlighted by the popular press, in academic work and in Commission reports. Table 1 provides evidence on price differences within the EU around the time the single currency was introduced. Even though various sources were used, all entries in the table relate to identical, branded items and can thus justifiably be used for price comparisons. Some also feature in the analysis later in this paper.

The differences are substantial, all double digit values in percentage terms, ranging from $18 \%$ (Monopoly game) to $74 \%$ (Swatch watch). Some countries appear more than once in the 'low' or 'high' price columns, such as the UK which has repeatedly been shown to be a fairly expensive country in price surveys. Despite this, an interesting feature of the table is that most countries feature in both the low and high price columns, indicating that relative prices also differ 
substantially across countries. Although this is fairly ad hoc sample. the comparisons in Table 1 illustrate that European consumers often pay very different prices for identical products. Even though the prices in the table include taxes, the differences are much to big for variations in sales taxes to play a major role.

The question taken up in this paper is whether the introduction of the single currency has led to a narrowing of such price differences. That a single currency would have such an effect was first argued by the European Commission in its influential One Market, One Money (1990) publication:

Without a completely transparent and sure rule of the law of one price for tradable goods and services, which only a single currency can provide, the single market cannot be expected to yield its full benefits - static and dynamic. (p. 19, italics added).

According to the Commission, a single currency would deepen economic integration in a number of ways. First, the costs of doing business in other member countries would be reduced due to the reduction in exchange rate premia (payable, for instance, on forward contracts). Second, lower uncertainty would make cross-border business more profitable, since lower risks would translate into higher risk-adjusted rates of return. Third, international transactions would become cheaper due to the elimination of currency exchange costs and reduced delays. The direct costs of foreign transactions in the EU were estimated by the Commission at between one-half and one percent of GDP.

In a background paper to its 1996 single market review the Commission (1996) added a fourth potential benefit of the single currency. As a result of 'one money'

... increased price transparency will enhance competition and whet consumer appetites for foreign goods; price discrimination between different national markets will be reduced ... (p. 74).

And, when it was finally introduced in 1999, the Commission (1999, p.2) repeated its conviction that the euro would "squeeze price dispersion in EU 
markets". ${ }^{1}$

Recent theoretical work has added some additional insights. A common theme is that currency unions may alter the way firms set prices. Devereux et al. (2002), for instance, argue that, when the euro develops into a vehicle currency for international trade, firms outside the euro area will tend to set common prices for the entire euro-area. Friberg (2001) shows that firms that price-discriminate internationally will adopt different pricing strategies under a common currency compared to a regime of fixed exchange rates. However, greater price convergence as a result of a common currency is not a foregone conclusion. Firms may respond to an exogenous lowering of arbitrage costs - e.g. via a common currency - by endogenously introducing greater arbitrage barriers to raise the degree of market segmentation, e.g. through vertical restraints, bundling with nontradables or technical differentiation. Friberg and Martensen (2001) show that in this case lower transaction costs could lead to greater price differences.

Empirically, the potential effects of currency unions on economic integration have recently generated a lively debate following the publication of a study by Andrew Rose (2000). He found that currency unions are associated with a large increase in trade between participating countries, even after controlling for a variety of other characteristics shared between such countries. While a number of subsequent papers (Persson 2001, Melitz 2001, and others) have subsequently questioned his results, in particular the magnitude of the effect, there is little doubt that trade flows tend to be higher for countries in a currency union. ${ }^{2}$ This suggests that the widely discussed home-bias in international trade (McCallum 1995, Helliwell 1998) and border effect on prices (Engel and Rogers 1996) may

\footnotetext{
${ }^{1}$ Similar views were voiced by European consumer organisations. Jim Murray, director of the BEUC (Bureau Européen des Unions de Consommateurs), for instance argued that "the euro should help to reduce these price differences", but also conceded that it would "not in itself bring full price convergence" (BEUC 1998).

2 There are many studies related to Andrew Rose's work, including his own subsequent work. A useful list can be found on Rose's homepage under http://faculty.haas.berkeley.edu/arose/RecRes.htm.
} 
in part be due to the use of different currencies across countries.

Three recent studies have also examined price convergence in the EU and the potential role of the common currency. Rogers et al. $(2001)^{3}$ and Parsley and Wei (2001) study a greater array of goods prices than that covered in this paper, but from the same source (Economist Intelligence Unit). Rogers et al. study data up to 1999 and, although they do not explicitly attempt to identify a currency union effect, they report that price dispersion fell during the 1990s, with most of this reduction occurring between 1990 and 1995. Parsley and Wei (2001) extend the sample to 2000 and explicitly address the potential EMU effect. Based on a gravity equation, they report a significant reduction in price dispersion due to the introduction of the euro for the EMU member countries. However, their study is based on a measure of the dispersion of relative rather than absolute prices ${ }^{4}$. Due to this difference in measurement, Parsley and Wei's results are not strictly comparable to those provided here. Lutz (2002) examines price differences in the European car market during 1993-98 and reports that price differences for the one existing currency union - between Luxembourg and Belgium - are significantly smaller than for other country pairs, even after controlling for a variety of other potential determinants.

\section{Methodology and estimation strategy}

The issue addressed in this paper is a classic policy evaluation question. There is a substantial literature on the evaluation of economic policies, particularly in labour economics (e.g. Angrist and Krueger 1999), which provides the basis for

\footnotetext{
${ }^{3}$ Rogers (2001) is a closely related paper.

${ }^{4}$ The measure is the standard deviation of the common currency price differential across different goods for each bilateral country comparison. The current study, in contrast, looks at the standard deviation of prices for a given good across countries. These two measures can give different results. For instance, when the ratios of the prices in country A are exactly the same in relation to those in country B, Parsley and Wei's measure of price dispersion would be zero, but this would not necessarily be the case for the relative standard deviation across prices.
} 
the empirical strategy employed here. This section follows Frondel and Schmidt (2001) who discuss the application of these tools to the evaluation of environmental policies. The discussion of the different estimators will be kept in general terms, referring to 'policy' or 'treatment' (borrowing from medical research) to denote the introduction of the single currency. Accordingly, the term 'treatment group' refers to the euro-zone countries. Of course, since the observation units of interest to this study are at a national level, potential datasets tend to be much smaller than those commonly used in labour studies where the units of observation are individuals or households.

Let the variable of interest that may be affected by the policy (in our case the degree of price dispersion among a group of countries) be denoted by $X_{r}^{j}$ where $j \in(Y, N)$ and $r \in\left(T, T^{\prime}\right) . Y$ identifies the group undergoing the treatment (here the 11 original EMU countries), $N$ the group(s) not affected by the treatment, $T$ denotes the treatment period (here the EMU period, i.e. 1999 and after) and $T^{\prime}$ non-treatment periods. We want to estimate the effect of a policy, i.e. the 'treatment effect'. and this is denoted by $-\Delta$. Ideally this would be estimated as the difference between the outcome for the treatment group after receiving the treatment (i.e. the degree of price dispersion among EMU member countries after the introduction of the euro), $X_{T}^{Y}-\Delta$, and the outcome the same group would have experienced had it not undergone the treatment, $X_{T}^{Y}$,

$$
S^{*}=\left(X_{T}^{Y}-\Delta\right)-X_{T}^{Y} .
$$

Thus $S^{*}$ is the ideal estimator of the treatment effect. The fundamental difficulty is that we cannot observe the counterfactual $X_{T}^{Y}$ with nonexperimental data. It needs to be replaced by an observable variable that serves as proxy (or instrument), necessitating certain identifying assumptions. A first, simple possibility is the before-after approach, where the treatment effect is estimated as

$$
S_{1}=\left(X_{T}^{Y}-\Delta\right)-X_{T^{\prime}}^{Y}
$$


and $X_{T^{\prime}}^{Y}$ denotes the outcome for the treatment group before the treatment period (i.e. price dispersion among EMU member countries before 1999). This necessitates the identifying assumption $E\left(X_{T}^{Y}\right)=E\left(X_{T^{\prime}}^{Y}\right)$, which implies in our case that price dispersion would not have changed over time had these countries not joined EMU.

A second possibility is the cross-sectional approach where a control group of non-participants is employed to replace the unobservable entity in 1 . This estimator, denoted by $S_{2}$, is given by

$$
S_{2}=\left(X_{T}^{Y}-\Delta\right)-X_{T}^{N}
$$

where identification requires that $E\left(X_{T}^{Y}\right)=E\left(X_{T}^{N}\right)$. This necessitates that selection into the treatment is independent of the outcome without the treatment. In our case, using $S_{2}$ to identify the treatment effect requires that there should be no fundamental differences between EMU countries and the control group which affect both the likelihood of participating in EMU and the degree of price dispersion among these countries had they not participated.

The third estimator ${ }^{5}$ employed here is based on the difference-in-differences (DD) approach, which can be thought of as a combination of the before-after and cross-sectional approaches. This estimator is denoted by $S_{3}$ and is given by

$$
S_{3}=\left[\left(X_{T}^{Y}-\Delta\right)-X_{T^{\prime}}^{Y}\right]-\left(X_{T}^{N}-X_{T^{\prime}}^{N}\right) .
$$

Comparing the changes in outcomes for treatment and control groups, this avoids the drawbacks of i) the cross-sectional approach by netting out fundamental differences between the two groups and ii) the before-after approach by netting out changes in the outcome variable affecting all groups. The as-

\footnotetext{
${ }^{5} \mathrm{~A}$ fourth method discussed in Frondel and Schmidt (2001) is the matching approach. This entails finding for each entity (individual, household, etc.) undergoing treatment a 'similar' or 'matching' entity (in terms of their general characteristics) not undergoing treatment to identify the treatment effect. This approach cannot be applied here due to the large data requirements. However, it implies that when using either cross-section or DD approaches the control group should as much as possible match the characteristics of the treatment group.
} 
sumption necessary to identify the treatment effect this way is $E\left(X_{T}^{Y}-X_{T^{\prime}}^{Y}\right)=$ $E\left(X_{T}^{N}-X_{T^{\prime}}^{N}\right)$. This requires that there are no other factors during the treatment period which influence the two groups differently. The DD approach has been successfully applied in a macroeconomic context by Slaughter (2001).

The outcome variable employed here is the estimated standard deviation of the logarithm of common-currency prices,

$$
s_{r t}^{j}=\sqrt{(G-1)^{-1} \sum_{i=1}^{G}\left(\ln P_{r t i}^{j}-\overline{\ln P_{r t}^{j}}\right)^{2}},
$$

where $G$ is the number of group members and $\overline{\ln P_{r t}^{j}}$ the mean across group members. Tests for a significant difference in dispersion between two time periods or two groups (say $A$ and $B$ ), as in the before-after and cross-sectional approaches, will be based on a standard $F$-test for the equality of two variances,

$$
\left[s_{A}^{2} /\left(G_{A}-1\right)\right] /\left[s_{B}^{2} /\left(G_{B}-1\right)\right] \sim F\left(G_{A}-1, G_{B}-1\right) .
$$

The DD approach will be implemented in a linear regression framework, such as

$$
s_{r t}^{j}=\alpha_{1}+\alpha_{2} D_{T}+\alpha_{3} D^{Y}+\alpha_{4} D_{T}^{Y}+\sum_{k=1}^{K} \beta_{k} Z_{k r t}^{j}+\varepsilon_{r t}^{j}
$$

where i) $D_{T}$, ii) $D^{Y}$ and iii) $D_{T}^{Y}$ are dummy variables equal to one when i) $r=T$, ii) $j=Y$ and iii) $r=T$ and $j=Y$ simultaneously, zero otherwise. The residual $\varepsilon_{r t}^{j}$ is assumed to have the usual desirable characteristics.

The dummy variables capture influences that are not directly measured but specific to the treatment and control groups and/or specific to periods before and during the treatment. Gravity equation estimates such as those discussed in the previous section usually also control for geographical factors such as distance and common borders, or whether countries share a common language. Thus, if there are differences in, for instance, average distances or language patterns across groups, their influence will be captured by $\alpha_{3}$. Similarly, changes in general factors which affect all groups alike (such as transportation costs) will 
be captured by $\alpha_{2}$. Overall, there is a direct mapping between the dummy effects and the terms used in the DD estimator in eq. (4):

$$
\begin{aligned}
\alpha_{1} & \rightarrow X_{T^{\prime}}^{Y} \\
\alpha_{1}+\alpha_{2} & \rightarrow X_{T}^{Y} \\
\alpha_{1}+\alpha_{3} & \rightarrow X_{T^{\prime}}^{Y} \\
\alpha_{1}+\alpha_{2}+\alpha_{3}+\alpha_{4} & \rightarrow X_{T}^{Y}-\Delta .
\end{aligned}
$$

The estimate of the DD effect in (4) is thus given by $\alpha_{4}$ and its statistical significance tested by considering the corresponding $t$-statistic. However, $\alpha_{4}$ only identifies the treatment effect if all factors with a differential effect on treatment and control groups during the treatment period are controlled for. Thus the $Z_{k r t}^{j}(k=1,2, \ldots K)$ terms in eq. (5) are additional control variables that are thought to influence price dispersion and vary over time and across groups. Three influences on prices dispersion are controlled for: i) differences in the extent of local-currency pricing of imports, ii) differences in the degree of exchange rate pass-through into prices of imported goods and iii) differences in the correlation of business cycle movements.

In addition to the specification shown in (5), results will also be presented for specifications i) where the dummies are interacted with time trends to allow for group- and period-specific changes in price dispersion, and ii) where both the dummies and differential time trends are included. To examine the sensitivity of the results further, both versions are estimated with and without the additional controls.

\section{Data description}

The analysis uses four different datasets on final goods prices:

- the prices of Big Macs that are published annually in The Economist,

- the cover prices of The Economist, 
- pre-tax car prices from Car Prices in the European Union, a survey of car prices regularly released by the European Commission, and

- data on the costs of various goods and services from Prices and Earnings around the Globe, a publication by the Swiss bank UBS.

All four datasets have in one form or another been used in previous work, usually to study issues related to the law of one price and market integration. The Big Mac prices, for instance, were used in Cumby (1996), Ong (1996) and Pakko and Pollard (1996). The Economist cover prices were employed, amongst others, in studies by Ghosh and Wolf (1994), Knetter (1997) and Knetter and Slaughter (1999). Lutz (1999), Gaulier and Haller (2000) and Goldberg and Verboven (2001) have utilised the European Commission's data on car prices and Lutz (2001) the UBS dataset.

Table 2 summarises the basic characteristics of the four datasets. They differ in various respects, such as the frequency that ranges from monthly (The Economist) to three-year intervals (the UBS data). They also cover different time spans and, as a result of the particular countries included, vary with respect to the composition of treatment and control groups. Moreover, the UBS data refers to specific cities while the other three datasets apply at the national level. Lastly, the car price data is unique here in being available before tax. Further details on the datasets can be found in the Appendix.

In an ideal situation, the treatment group would contain all eleven starting members of the euro-zone. As a natural control group, one might consider the remaining four EU member states. Ideally one would like to cover the 19952001 period, since Austria, Finland and Sweden were not formal EU members before then. In practice, however, several concessions had to be made due to the limitations of the data available. Thus in most cases either the selection of group members or time periods deviates in some dimension from the 'ideal' data set. The selection proceeded on the basis of the following considerations:

1. There had to be a sufficient number of observations for both treatment and control groups. For Big Mac prices and the UBS dataset this meant 
going further back than 1995 to obtain a sufficient number of observations (in both cases the entire available period was used).

2. For countries to be included, price data had to available without gaps. For Big Mac prices the treatment group thus only contains the four countries for which prices were listed throughout the period examined. The UBS based treatment group omits Ireland (since Dublin featured only intermittently) and Germany (since there is no German city with data throughout). With the European Commission reports not including Denmark, Finland and Greece until 1999, these three countries could not be included in the analysis, leaving a small control group only.

3. The UBS and car price datasets contain each more than one good or model. Only those series were included where prices were available for the entire set of countries in treatment and control groups. In addition, there had to be a sufficient number of consecutive observations over time (at least ten for each model and nine in the case of the UBS data). As a result, of more than 90 models covered at one point or another in the car price reports, only 17 had sufficient data. Similarly, of more than 30 individual price series featured at some point in the UBS price reports, only $13 \mathrm{had}$ a sufficient number of observations to be included.

To get a visual impression of the data, consider Figure 1 which shows the standard deviations of the logarithm of prices for both treatment and control groups for all four datasets. Considering the treatment group only - i.e. the EMU countries - there is not a lot of visual evidence that price dispersion decreased after 1999 except for The Economist cover prices. However, in this case prices for the control group appear to have converged too. Looking at the three other datasets one also finds that the behaviour of the control group exhibits a pattern similar to the treatment group during the most recent period. Since it is not easy to draw any straightforward conclusions from the diagrams alone, the next section undertakes a more thorough analysis employing the methods discussed earlier. 


\section{Estimates of the single currency effect}

This section presents the estimates of the single currency effect on price dispersion based on the various estimators discussed in section 3. As there are various estimators and test specifications, which are shown in Tables 3-8, the final table in this section (Table 9) provides a summary of the major results across datasets and test specification. This last table lists for each dataset and estimator i) the overall number of single currency estimates, ii) how many are negative and statistically significant, iii) how many are positive and significant and iv) what is called the 'net \%' and defined as the difference between ii) and iii) as a percentage of i). This last measure can theoretically range from $100 \%$ in the case where all estimates are significant and indicative of a downward single currency effect on price dispersion, and $-100 \%$ when all estimates are significant but point exactly the other way.

The first set of results is based on the before-after approach and presented in Table 3. Each entry in the table shows the ratio of the standard deviation during the first three years of EMU relative to the standard deviation during one of the previous three years. Thus nine comparisons are reported for each series with the exception of the UBS price series for which there are only three comparisons (due to the low sampling frequency). The last column in the table lists the mean for each series. Similarly, the last row gives the mean across series for each before-after comparison. A lowering of price dispersion during the EMU period is indicated by a ratio smaller than one, whereas values above one reflect an increase in price dispersion. The asterisks in the table indicate whether an $F$-test for the equality of each pair of variances reveals a statistically significant difference.

While there are many ratios below one, there are also many above one. As the before-after means indicate, there is little overall evidence of any systematic downward trend in the degree of dispersion for these price series. One exception is the Economist where the numbers in the table reflect the strong downward trend already visible in Figure 1. In this case, the before-after differences are also 
all statistically significant. In addition, four car models (Audi A4, Ford Fiesta and Focus, Mercedes S-class) indicate a significantly lower degree of price dispersion during EMU, at least for some of the comparisons. The same applies to five of the UBS series (food, women's clothing, rent, automobiles and restaurant meal), though mostly only with respect to 1991. At the same time, there are five car models and one UBS price series for which at least one of the before-after comparisons indicates a significantly higher degree of price dispersion during EMU. The overall result here - see the summary in Table 9 - is that, of all the 210 before-after comparisons in the table, 44 reveal a statistically significant difference and 32 of these support the hypothesis that the single currency has narrowed price differences.

The results for the cross-sectional comparisons are presented in Table 4 and organised in a similar way, the difference being that the comparisons now refer to the ratio of the standard deviation of EMU countries relative to that of a control group. Two control groups were employed, one consisting of the remaining EU countries and the other of a larger set of OECD countries (apart from car prices where the data source only contains EU countries). There are comparisons for each of the first three years of EMU, except for the UBS data where the low sampling frequency only allows one such comparison. Overall, the results based on the cross-sectional comparisons are more indicative of a significant lowering of price dispersion due to the single currency. As the summary in Table 9 shows, the 'net \%' measure rises to $22.5 \%$ in total, compared to $9.5 \%$ for the beforeafter comparisons. Thus those differences that are significant indicate in the majority of cases that price dispersion was lower for EMU countries than the two control groups. Nonetheless, the majority of estimates are again statistically insignificant. As regards the individual price series, it is again the Economist prices, and some of the UBS price series, that provide most evidence of an EMU effect. The evidence for car prices $^{6}$ is rather mixed.

\footnotetext{
${ }^{6}$ Note that some of the ratios of standard deviations are rather large due to the fact that the control group consists of only two countries, the UK and Sweden. In those cases where prices happen to be fairly similar between the two countries, the estimated standard deviation
} 
Both the before-after and the cross-sectional approaches are useful devices to describe the basic patterns found in the data but have their limitations. In particular, as discussed earlier, they can only provide direct evidence of the single currency effect on price dispersion under very certain, rather stringent, conditions. The requirement in the case of the before-after approach is that price dispersion would not have changed over time had these countries not joined EMU. This is clearly a very strong assumption, since there are potentially many other factors which may have influenced the degree of price dispersion - one only needs to think improvements in transport and transaction technologies such as the internet. The cross-sectional approach requires that EMU and non-EMU countries are completely alike apart from participation in the monetary union. This, too, may be an unrealistic assumption here. It is quite likely, for instance, that countries forming a currency union are more integrated to start off with. In this case they will have a lower degree of price dispersion independently of the single currency and the cross-sectional estimates can therefore not be used to identify its effect.

The Results in Tables 5-8 are based on the difference-in-differences (DD) approach which, as discussed in section 3 , eliminates these problems ${ }^{7}$ by controlling for both additional influences and differences between treatment and non-treatment groups. All the estimates are based on variants of equation (5). The corresponding $t$-ratios are shown in parentheses. Each table contains three DD estimates: the first relates to DD estimates of the differences in the level of price dispersion (denoted by 'shift' in the column header), the second to differences in the trend in price dispersion (denoted by 'change in trend' in the column header) and the third allows for both simultaneously. To save space, only the estimates of the single currency effect are reported in the tables. Summary results are again provided in Table 9. Depending on specification, not will be very small and thus the ratio of the two standard deviations rather large. This also affects the means of the point estimates.

${ }^{7}$ Note that the DD approach naturally also controls for (constant) differences in measurement, such as the different number of countries in each group. 
all datasets feature for all specifications and/or comparisons due to the data limitations discusses previously.

The four tables report differ in terms of control group ('other EU' countries in Tables 5 and 6, 'other OECD' countries in Tables 7 and 8) and inclusion of control variables. Tables 6 and 8 contain three additional controls: i) the standard deviation of inflation rates to capture differences in the extent of localcurrency pricing; ii) the standard deviation of exchange rate growth rates (visa-vis the US dollar) to capture differences in the degree of exchange rate passthrough into import prices; and iii) the standard deviation of output growth rates to capture differences in the degree to which business cycle movements are correlated. All three variables are group- and time-specific.

Table 5 contains the 'basic' DD estimates with EU control group and no additional controls. There are no 'change in trend' estimates for the UBS price series since there is only one observation during the EMU period. 21 of the total 32 estimates of the 'shift' estimates are negative, indicating a lowering of price differences due to the single currency for the majority of cases. Ten of these negative estimates are also statistically significant. However, there are also five that are positive and significant. For the 'change in trend' specification, the results are even less clear-cut. There are ten positive and nine negative estimates; five of each are also statistically significant. The third specification, where both types of effects are allowed for, provides the weakest evidence of a lowering of price dispersion due to the single currency. Here the majority of all point estimates (25 positive versus 13 negative) and the majority of all those that are significant (eight versus two) are positive.

Looking at the evidence across individual price series, there are fourteen for which there is at least one significant negative estimate, but there are also nine with at least one significant positive estimate. Most of the evidence for a downward single currency effect comes from a number of car models (Audi A4, Ford Fiesta and Focus, Opel Corsa, Vectra and Omega, Peugeot 306 and Renault Laguna) and some of the UBS series. In contrast, most of the estimates for the Economist are now positive, indicating that while price dispersion may 
have narrowed for the EMU countries (as indicated by the before-after approach) and has generally been lower than for non-EMU countries (as indicated by the cross-sectional approach), the change during the EMU period has been more negative for the latter group of countries. In contrast, the evidence for Big Mac prices has not changed: both statistically significant estimates are still positive.

How sensitive are these 'basic' DD results to a change in control group and the addition of further control variables? Table 6 examines what happens when the three control variables described above are added to the DD regression (again, to save space, the table only reports the DD estimates). Overall, there is even less evidence of a negative single currency effect on price dispersion. As the summary in Table 9 shows, of all 89 estimates in the table there are only 16 that are significantly negative but 19 that are significantly positive, compared to 19 versus 18 in the case without controls (in Table 5). Looking at the individual price series in Table 6, the results for Big Mac prices have remained the same, while those for the Economist are now more indicative of a negative single currency effect with two significantly negative DD estimates. For the UBS price series, there are now only two significantly positive estimates compared to three before. However, for the car price series there are now fifteen positive and significant estimates but only nine negative and significant estimates (compared to 14 versus 12 without controls in Table 5). Adding controls has therefore not increased the overall evidence of a significant downward effect of EMU on price dispersion.

Tables 7 and 8 report the estimates for the same exercises but now with the larger set of OECD countries as control group. There are fewer estimates than before because the car price dataset features only EU countries. Changing the control group renders the evidence based on Big Mac prices even less favourable of a negative single currency effect, as there are now three rather than the previous two significantly positive estimates both with and without additional controls. In contrast, Economist prices are now more supportive of a downward single currency effect, with three rather than two significantly negative estimates (regardless of whether the extra control variables are included or not) compared 
to the estimates with the EU country control group. The evidence on the UBS price data is mixed. There are now fewer significant estimates overall, and the 'net effect' has become more supportive of the downward single currency effect in the specification without controls but less favourable when the control variables are included.

Table 9.gives a summary impression of the results from this section. In total, there are 519 estimates of the single currency effect, differing in terms of price series, dataset, estimator and control group employed. Of these, 103 provide statistically significant evidence that the single currency has reduced the degree of price dispersion among the member countries. However, there are also 64 tests where the results are statistically significant but pointing in the other direction, i.e. an upward effect on price dispersion due to the single currency. The overall evidence is thus not very strong. If one cancels the statistically negative and positive estimates against each other, the net effect left amounts to $7.5 \%$ of the total number of tests.

There are some differences across datasets, though. The evidence based on Big Mac prices, for instance, provides little support for the European Commission's claims. The car price results are sensitive to the inclusion of additional controls. Considered across all test, they do not support a single currency effect in either direction. The strongest evidence of a downward single currency effect on price differences comes from the cover prices of the Economist. Some support of the Commission's claims can be found among the UBS price series, though it is far from decisive. Looking across the various estimators, the cross-sectional approach is most indicative of the downward EMU effect on price differences, followed by the before-after estimates. However, as discussed earlier, both approaches have their drawbacks. The DD approach, which is probably a better way to isolate the pure single currency effect on price dispersion, lends practically no support to the European Commission's claims, irrespective of which control group is used and whether additional control variables are added or not. 


\section{Conclusion}

The results in this paper suggest that there is little evidence so far that EMU has led to a narrowing of price differences during the first three years, at least for the goods prices studied here. Taken at face value, this suggests that the use of different currencies has not exerted a significant influence on the degree of market segmentation across the European Union. This may not only come as a surprise given the statements made by the European Commission and other commentators in the run-up to monetary union, but also when one considers the recent evidence on the effect of common currencies on trade. It is therefore natural to ask whether the evidence provided in this paper is truly indicative of a general pattern. Could it be unrepresentative - possibly even biased - as a result of the particular data and method employed?

The reader may, for instance, question whether the small selection of goods covered in this paper is indicative of more general price trends. A thorough answer can only be provided by considering a larger number of goods, but there is currently only a very limited number of datasets reporting the prices of individual goods. One advantage of the results presented here is that they are based on four independent datasets. There is thus no reason to suspect an inherent bias in the collection of the data. A second advantage is that very different types of goods and services are covered, thus reducing the potential for selection biases. It is therefore not easy to argue that the results of this study would be inherently biased against finding a significant single market effect.

A second possible limitation may be the short EMU time period covered in the paper. Nevertheless, given the fairly high profile price differences have received in the press and the discussions on the pros and cons of monetary union, it is useful to have at least an intermediate report on the story so far, even if we remain unsure about the long run effects of the single currency. We should also remind ourselves that Rogoff's (1996) stylised facts on PPP report half-lives in the range of three to five years, and that there is newer work with evidence of even faster convergence (e.g. Taylor 2001). It is thus not unreasonable to expect 
to find some evidence of a narrowing of price differentials within a three-year period, if the single currency really has such an effect.

A related point is whether one should draw a distinction between the first three years of EMU and the period from 2002 onwards. Could it matter whether people have actual notes and coins in their hands? The standard answer is no, if agents are rational and therefore capable of telling the difference between nominal (i.e. prices in different currencies) and real variables (i.e. relative prices between countries). However, the evidence in Fehr and Tyran (2001) suggests that money illusion may after all be a real phenomenon ${ }^{8}$. It will be interesting to see whether the introduction of actual euro notes and coins has a separate effect on price convergence but, again, evidence on this will only be available in a few years' time.

A third response to the findings presented in this paper is to accept that there are many other factors determining the degree of product market integration in the EU. Some goods and services are nontradable by nature. Others are rendered nontradable in practice due to lack of competition between producers as well as distributors, transport and other transaction costs, and informational asymmetries between local and foreign consumers about local prices. It is possible that, because of all these other constraints on market integration, the single currency has so far had such a negligible effect on price dispersion in the EMU.

\footnotetext{
${ }^{8}$ Their experimental setup - where 'money illusion' is driven by strategic complementarities between price-setters - may not be strictly applicable to the single currency issue, but sheds an interesting light on the mechanisms underlying price rigidities. Moreover, there is strong evidence of 'framing effects' in the experimental literature and perhaps a particular currency also serves as a reference frame to agents.
} 


\section{References}

[1] Angrist, J. and A. Krueger (1999). Empirical strategies in labor economics. In O. Ashenfelter and D. Card (eds.), Handbook of Labor Economics, Vol. 3, Elsevier Science: pp. 1277-1366.

[2] BEUC (1998). A single price for a single currency? BEUC Press Release, December 21, 1998.

[3] Commission of the European Communities (1990). One market, one money: an evaluation of the potential benefits and costs of forming an economic and monetary union. European Economy, No. 44, October 1990.

[4] Commission of the European Communities (1996). The 1996 single market review - background information for the report to the council and European parliament. Commission Staff Working Paper, SEC (96) 2378, Brussels, 16/12/1996.

[5] Commission of the European Communities (1999). Report on economic and structural reform in the EU. European Economy, Supplement A, Economic Trends, No. 1, January 1999.

[6] Cumby, R. (1996). Forecasting exchange rates and relative prices with the hamburger standard: is what you want what you get with McParity? NBER Working Paper No. 5675. NBER, Cambridge, MA.

[7] Devereux, M., C. Engel and C. Tille (2002). Exchange-rate pass-through and the welfare effects of the euro. International Economic Review, forthcoming.

[8] Engel, C. and J. Rogers (1996). How wide is the border? American Economic Review 86, 1112-1125.

[9] European Commission. Car Prices in the European Union. Bruxelles: Directorate-General IV-Competition. Various issues.

[10] Fehr, E. and Tyran, J. (2001). Does money illusion matter? American Economic Review 91, pp. 1239-1262.

[11] Friberg, R. (2001). Two monies, two markets? Variability and the option value to segment. Journal of International Economics 55, pp. 317-327.

[12] Friberg, R. and K. Martensen (2001). Endogenous market segmentation and the law of one price. Working Paper Series in Economics and Finance 471. Stockholm School of Economics.

[13] Frondel, M. and C. Schmidt (2001). Evaluating environmental programs: the perspective of modern evaluation research. IZA Discussion Paper No. 397, November. 
[14] Gaulier and Haller (2000). The convergence of automobile prices in the European Union: an empirical analysis for the period 1993-99. CEPII Working Paper 2000-14.

[15] Ghosh, A. and Wolf, H. (1994). Pricing in international markets: lessons from The Economist. NBER Working Paper No. 4806. Cambridge, MA.

[16] Goldberg, P. and F. Verboven (2001). Market integration and convergence to the law of one price: evidence from the automobile industry. NBER Working Paper No. 8402. Cambridge, MA.

[17] Helliwell, J. (1998). How Much Do National Borders Matter? Washington, D.C.: Brookings Institution Press.

[18] Knetter, M. (1997). The segmentation of international markets: evidence from The Economist. NBER Working Paper No. 5878. Cambridge, MA.

[19] Knetter, M. and Slaughter, M. (1999). Measuring product market integration. NBER Working Paper No. 6969. Cambridge, MA.

[20] Lutz, M. (1999). EU Commission versus Volkswagen: new evidence on price differentiation in the European car market. The Review of Industrial Organization 17 (3): 313-323.

[21] Lutz, M. (2001). Beyond Burgernomics and MacParity: exchange rate forecasts based on the law of one price. Mimeo, University of St. Gallen, Switzerland.

[22] Lutz, M. (2002). Pricing in segmented markets, arbitrage barriers and the law of one price: evidence from the European car market. Review of International Economics, forthcoming.

[23] McCallum, J. (1995). National borders matter: Canada-U.S. regional trade patterns. American Economic Review 85: 615-623.

[24] Melitz, J. (2001). Geography, trade and curreny union. CEPR Discussion Paper No. 298\%. CEPR, London.

[25] Ong, L. (1997). Burgernomics: the economics of the Big Mac standard. Journal of International Money and Finance 16: 865-78.

[26] Pakko, M. and Pollard, P. (1996). For here or to go: purchasing power parity and the Big Mac. Federal Reserve Board of St. Louis Review, Jan/Feb.

[27] Parsley, D. and Wei, S. (2001). Limiting currency volatility to stimulate goods market integration: a price based approach. NBER Working Paper No. 8468. Cambridge, MA.

[28] Persson, T. (2001). Currency unions and trade: how large is the treatment effect? Economic Policy 33: 434-448. 
[29] Rogers, J. (2001). Price level convergence, relative prices and inflation in Europe. International Finance Discussion Paper No. 699. Board of Governors of the Federal Reserve System, Washington, DC.

[30] Rogers, J., Hufbauer, G. and Wada, E. (2001). Price level convergence and inflation in Europe. Working Paper 01-1. Institute for International Economics, Washington, DC.

[31] Rogoff, K. (1996). The purchasing power parity puzzle. Journal of Economic Literature 34:647-68.

[32] Rose, A. (2000). One money, one market: the effect of common currencies on trade. Economic Policy 30: 7-45.

[33] Slaughter, M. (2001). Trade liberalisation and per capita income convergence: a difference-in-difference analysis. Journal of International Economics 55: 203-228.

[34] Taylor, A. (2002). A century of purchasing power parity. Review of Economics and Statistics 84: 139-150. 


\section{Appendix Description of the Data}

- Big Mac prices have been published annually by The Economist for a number of countries since 1986, usually in April. Following Cumby (1996) the first two BMI surveys in 1986 and 1987 were merged, since they are only a few months apart (September 1986 and January 1987) and cover only a limited number of countries each. So, for countries with no observation for 1987, I use the 1986 value. The exact timing of the data is as follows: $17 / 1 / 1987$ (or $1 / 9 / 1986$ ), $28 / 3 / 1988,11 / 4 / 1989,30 / 4 / 1990$, 9/4/1991, 10/4/1992, 13/4/1993, 5/4/1994, 7/4/1995, 22/4/1996, 7/4/1997, $6 / 4 / 1998,30 / 3 / 1999,25 / 4 / 2000,17 / 4 / 2001$. For the analysis I use the prices in US dollars from the Economist's tables.

- The Economist cover prices were taken from the European issue on sale in Switzerland. Prices in different currencies first appeared in 1966, including 13 industrialised countries. Following Knetter (1996) I use the prices on the last issue of each month. For the US and UK, December prices were set equal to the normal price (and not the higher price for the Christmas issue). To convert the prices into US dollars, end-of-period ex-change rates (code ..AE.ZF) from the IMF's International Financial Statistics database were employed.

- Car prices. The European Commission has published a detailed list of recommended retail prices for the most popular models on a biannual basis since 1993. The prices refer to the 1st of May and the 1st of November of each period. In contrast to the other three datasets, the car prices used here are pre-tax prices. The analysis covers the 1995-2000 surveys, since Austria and Sweden only joined the EU in 1995 and did not feature in the earlier reports. Only the 17 models used in this survey had data available for at least ten consecutive periods for the countries in the treatment and control groups. Data up to the 1998 surveys were converted into ecus and those from 1999 into euros using the exchange rates given in the data volumes.

- UBS price surveys. UBS has released its survey on Prices and Earnings Round the Globe since 1971. There have been eleven issues of the survey so far, the last appearing in 2000. The data collection periods were July 1970, July/Aug 1973, May/June 1976, June/July 1979, March/April 1982, spring 1988 and 1991, and the second quarter in 1994, 1997 and 2000. The surveys provide data on the prices of various types of goods at different levels of aggregation sampled in major cities around the world. The surveys include between 31 and 58 major cities, some located in the same country. Overall, 66 cities from 55 countries have appeared in one or more issues so far. The cities used in this paper are Vienna (Austria), Sydney (Australia), Brussels (Belgium), Montreal (Canada), Copenhagen (Denmark), Helsinki (Finland), Paris (France), Athens (Greece), Milan (Italy), 
Tokyo (Japan), Luxembourg (Luxembourg), Amsterdam (Netherlands), Oslo (Norway), Lisbon (Portugal), Madrid (Spain), Stockholm (Sweden), Zurich (Switzerland), London (UK) and New York (USA). Dublin did not feature in the first two surveys, and none of the German cities appears throughout. Only those price series are included that have appeared in at least nine consecutive surveys, including the 2000 issue. These are:

- Basket of goods and services: 1976-2000 (1976 value excl. rent), cost of a basket of goods and services, including rent, weighted (equally across countries) by consumer habits.

- Food prices: 1970-2000, the cost of a food basket.

- Men's and women's clothing: 1970-2000, cost of purchasing a number of items.

- Rent: 1973-2000, rent for a 4room furnished apartment.

- Household appliances: 1970-2000, cost of purchasing several appliances such as TV, refrigerator etc.

- Public transport: 1973-2000, price of a one-way ride on public transport (bus, streetcar or subway) of about $10 \mathrm{~km}$ (6 miles) or at least 10 stops.

- Taxi ride: 1973-2000, price of a $5 \mathrm{~km}$ ride (3miles) during daytime within city limits.

- Automobile service: 1976-2000, average labour costs (not including price of spare parts, if needed, and oil change) for a $15000 \mathrm{~km}$ (approx. 9000 miles) check-up.

- Restaurant meal: 1970-2000, price of a dinner for one (price of a main dish in 1970 and 1973).

- Hotel stay: 1970-2000, cost of a double room with bath and breakfast for two, incl. service, in a first class hotel.

- Basket of services: 1970-2000, cost of a weighted basket of between 10 and 28 items.

- Automobile: 1970-2000, price of a medium-sized automobile (but models vary across countries and over time).

- The data on exchange rates, growth and inflation used as additional controls in the DD estimates are taken from the August 2002 CD-Rom edition of the IMF's International Financial Statistics.

- Estimates for The Economist prices:

* Exchange rate: monthly growth rates of end-of-period exchange rates (code ..AE.ZF). 
* Output: monthly equivalent of year-on-year growth rates of quarterly real GDP (code ..99BV..), except for Greece (manufacturing production up to 2000; annual GDP for 2001), Iceland (annual real GDP), Ireland (industrial production), Luxembourg (industrial production up to 2000:6; annual GDP for 2000:7-2001:12), Norway (no data for 2001:4-2001:12, so assumed same growth rate as 2001:1-2001:3) and Portugal (2001 based on annual data).

* Inflation: monthly equivalent of year-on-year growth rates of monthly consumer price index (code ..64..ZF..), except for Ireland (quarterly CPI data up to 1996:12).

- Estimates for Big Mac prices:

* Exchange rate: annual growth rates of first quarter end-of-period exchange rates (code ..AE.ZF).

* Output: annual growth rates of first quarter real GDP (code ..99BV..), except for Denmark (annual GDP data), Ireland (industrial production), and Luxembourg (industrial production up to 2000; annual GDP for 2001).

* Inflation: annual growth rates of first quarter consumer price index (code ..64..ZF..).

- Estimates for car prices:

* Exchange rate: six-monthly growth rates of April and October end-of-period exchange rates (code ..AE.ZF).

* Output: six-monthly growth rates of second and fourth quarter real GDP (code ..99BV..), except for Ireland (industrial production), Luxembourg (industrial production up to 2000:II and annual GDP data after that) and Portugal (2001 based on annual data).

* Inflation: six-monthly growth rates of April and October consumer price index (code ..64..ZF..), except for Ireland (quarterly CPI data up to 1996:12).

- Estimates for UBS price series:

* Exchange rate: three-year growth rates of second quarter end-ofperiod exchange rates (code ..AE.ZF).

* Output: three-year growth rates of annual real GDP (code ..99BV..), except for Luxembourg (industrial production; annual GDP for 2000).

* Inflation: three-year growth rates of second quarter consumer price index (code ..64..ZF..). 
Figure 1. Standard Deviations Over Time

Notes: The panel containing the car price data shows the mean standard deviation across 17 models and that for the UBS data the mean standard deviation across 13 series. 


\begin{tabular}{llcccc}
\hline & Item & $\begin{array}{c}\text { Price } \\
\text { difference }\end{array}$ & Low & High & Date \\
\hline 1 & The Economist & $58 \%$ & Greece & Denmark & Dec. 1998 \\
2 & Big Mac & $41 \%$ & Spain & Denmark & Apr. 1998 \\
3 & Canon Prima Super 135 (camera) & $73 \%$ & Germany & UK & Jun. 1999 \\
4 & Lacoste polo shirt & $27 \%$ & Spain & Austria & Jun. 1999 \\
5 & Swatch "The Classics" & $74 \%$ & Italy & UK & Jun. 1999 \\
6 & Chanel No 5 (perfume) & $59 \%$ & Belgium & UK & Jun. 1999 \\
7 & Levi's 501 (jeans) & $34 \%$ & Italy & Germany & Jun. 1999 \\
8 & Kellog's cornflakes & $28 \%$ & UK & Germany & Nov. 1999 \\
9 & Top 5 DVD & $29 \%$ & Germany & France & Nov. 1999 \\
10 & Duracell batteries, 4pack & $36 \%$ & France & UK & Nov. 1999 \\
11 & Monopoly (game) & $18 \%$ & France & Germany & Nov. 1999 \\
12 & Sega Dreamcast & $25 \%$ & Germany & UK & Nov. 1999 \\
13 & Ford Mondeo & $54 \%$ & Spain & Portugal & Nov. 1998 \\
14 & VW Golf & $30 \%$ & Luxembourg & Ireland & Nov. 1998 \\
15 & Peugeot 406 & $28 \%$ & Luxembourg & Portugal & Nov. 1998 \\
16 & BMW 3-series & $41 \%$ & Sweden & Ireland & Nov. 1998 \\
17 & Fiat Punto & $33 \%$ & France & Ireland & Nov. 1998 \\
\hline
\end{tabular}

Table 1. Price Differences in the European Union, Some Examples

Notes: The cover prices of The Economist and the Big Mac prices are taken from the 19 December 1998 and 6 April 1998 issues, respectively. Data for items 3-7 comes from 'A Single Price for a Single Currency?', a BEUC Press Release dated 21 December 1998. This reports prices from a survey covering major cities in 10 EU countries, which was undertaken in June 1998. Data for items 8-12 are taken from 'A Report into International Price Comparisons', prepared for the UK Department of Trade and Industry by ACNielsen and released on 13 February 2000. The report covers prices in France, Germany, UK and US surveyed in November and December 1999. The car price data (items 13-17) is taken from European Commission (1998), Car Prices in the European Union on 1 November 1998, which covers 12 EU countries. 


\begin{tabular}{|c|c|c|c|c|}
\hline & Big Mac & Economist & Cars & $U B S$ \\
\hline Period & $1987-2001$ & $1995-2001$ & $1995-2001$ & $1970-2000$ \\
\hline Frequency & annual & monthly & bi-annual & every three years \\
\hline $\begin{array}{l}\text { Number of } \\
\text { series }\end{array}$ & 1 & 1 & 17 & 13 \\
\hline $\begin{array}{l}\text { EMU } \\
\text { countries }\end{array}$ & $\begin{array}{l}\text { France, Germany, } \\
\text { Italy, Spain }\end{array}$ & $\begin{array}{l}\text { Austria, Belgium, } \\
\text { Finland, France, } \\
\text { Germany, Ireland, } \\
\text { Italy, Luxembourg, } \\
\text { Netherlands, Portugal, } \\
\text { Spain }\end{array}$ & $\begin{array}{l}\text { Austria, Belgium, } \\
\text { France, Germany, } \\
\text { Ireland, Italy, } \\
\text { Luxembourg, } \\
\text { Netherlands, Portugal, } \\
\text { Spain }\end{array}$ & $\begin{array}{l}\text { Austria, Belgium, } \\
\text { Finland, France, Italy, } \\
\text { Luxembourg, } \\
\text { Netherlands, Portugal, } \\
\text { Spain }\end{array}$ \\
\hline $\begin{array}{l}\text { Other EU } \\
\text { countries }\end{array}$ & $\begin{array}{l}\text { Denmark, } \\
\text { Sweden, UK }\end{array}$ & $\begin{array}{l}\text { Denmark, Greece, } \\
\text { Sweden, UK }\end{array}$ & Sweden, UK & $\begin{array}{l}\text { Denmark, Greece, } \\
\text { Sweden, UK }\end{array}$ \\
\hline $\begin{array}{l}\text { Other OECD } \\
\text { countries }\end{array}$ & $\begin{array}{l}\text { Australia, } \\
\text { Canada, Japan, } \\
\text { USA }\end{array}$ & $\begin{array}{l}\text { Iceland, Norway, } \\
\text { Switzerland, USA }\end{array}$ & & $\begin{array}{l}\text { Australia, Canada, Japan, } \\
\text { Norway, Switzerland, } \\
\text { USA }\end{array}$ \\
\hline
\end{tabular}

Table 2. Description of the Four Datasets

Notes: The UBS data is based on prices observed in cities. The cities are Vienna (Austria), Sydney (Australia), Brussels (Belgium), Montreal (Canada), Copenhagen (Denmark), Helsinki (Finland), Paris (France), Athens (Greece), Milan (Italy), Tokyo (Japan), Luxembourg (Luxembourg), Amsterdam (Netherlands), Oslo (Norway), Lisbon (Portugal), Madrid (Spain), Stockholm (Sweden), Zurich (Switzerland), London (UK), New York (USA). 


\begin{tabular}{|c|c|c|c|c|c|c|c|c|c|c|}
\hline & $\begin{array}{r}1999 \\
v s . \\
1998\end{array}$ & $\begin{array}{r}1999 \\
v s . \\
1997\end{array}$ & $\begin{array}{r}1999 \\
v s . \\
1996\end{array}$ & $\begin{array}{r}2000 \\
v s . \\
1998\end{array}$ & $\begin{array}{r}2000 \\
v s . \\
1997\end{array}$ & $\begin{array}{r}2000 \\
v s . \\
1996\end{array}$ & $\begin{array}{r}2001 \\
v s . \\
1998\end{array}$ & $\begin{array}{r}2001 \\
v s . \\
1997\end{array}$ & $\begin{array}{r}2001 \\
\text { vs. } \\
1996\end{array}$ & Mean \\
\hline Big Mac & 1.31 & 1.50 & 1.25 & 1.32 & 1.51 & 1.51 & 1.38 & 1.57 & 1.31 & 1.41 \\
\hline The Economist & $0.52 * *$ & $0.57 * *$ & $0.38 * *$ & $0.27 * *$ & * $0.30 * *$ & $0.30 * *$ & $0.23 * *$ & $0.26 * *$ & $0.17 * *$ & 0.33 \\
\hline Audi A4 & 0.75 & 0.72 & $0.57 * *$ & 1.00 & 0.95 & 0.75 & 0.86 & 0.82 & $0.65 *$ & 0.78 \\
\hline Ford Fiesta & 0.85 & $0.65 *$ & 0.95 & 0.77 & $0.59 * *$ & 0.87 & $0.66 *$ & $0.50 * *$ & 0.74 & 0.73 \\
\hline Ford Focus (Escort) & 0.94 & $0.57 * *$ & $0.58 * *$ & 0.96 & $0.58 * *$ & $0.59 * *$ & 1.36 & 0.83 & 0.84 & 0.81 \\
\hline Ford Mondeo & 0.91 & 0.98 & 0.81 & 1.05 & 1.13 & 0.93 & 0.98 & 1.05 & 0.87 & 0.97 \\
\hline Mercedes S-Class & 0.92 & $0.43 * *$ & $0.47 * *$ & 1.02 & $0.48 * *$ & $0.52 * *$ & $0.66 *$ & $0.31 * *$ & $0.34 * *$ & 0.57 \\
\hline Opel Corsa & 1.09 & 0.77 & 0.78 & $1.55 *$ & 1.09 & 1.11 & $2.32 * *$ & $1.64 *$ & $1.66 *$ & 1.33 \\
\hline Opel Astra & 1.45 & $1.52 *$ & 1.39 & 1.25 & 1.31 & 1.20 & 1.49 & $1.56 *$ & 1.42 & 1.40 \\
\hline Opel Vectra & 1.17 & 1.43 & 1.05 & 1.30 & $1.58 *$ & 1.16 & 1.48 & $1.81 * *$ & 1.32 & 1.36 \\
\hline Opel Omega & 0.94 & 0.85 & 0.96 & 0.79 & 0.71 & 0.80 & 0.88 & 0.79 & 0.89 & 0.85 \\
\hline Peugeot 306 (307) & 0.97 & 0.88 & 1.16 & 0.93 & 0.84 & 1.11 & 0.97 & 0.88 & 1.16 & 0.99 \\
\hline Renault Laguna & 1.15 & 0.92 & 1.24 & 1.04 & 0.83 & 1.12 & 0.98 & 0.78 & 1.05 & 1.01 \\
\hline Seat Ibiza & 1.29 & 1.26 & $1.73 * *$ & 1.01 & 0.99 & 1.35 & 1.00 & 0.98 & 1.35 & 1.22 \\
\hline Seat Toledo & 1.14 & 0.73 & 0.92 & 1.08 & 0.70 & 0.88 & 1.31 & 0.85 & 1.07 & 0.96 \\
\hline Toyota Avensis (Carina) & 1.28 & 0.79 & 1.24 & 1.24 & 0.77 & 1.20 & 1.30 & 0.80 & 1.25 & 1.10 \\
\hline VW Golf & 1.40 & 1.28 & 1.25 & 1.49 & 1.36 & 1.33 & 1.48 & 1.35 & 1.32 & 1.36 \\
\hline VW Passat & $1.52 *$ & 1.16 & 0.82 & 1.41 & 1.07 & 0.76 & $1.60 *$ & 1.22 & 0.87 & 1.16 \\
\hline Volvo S40 (440) & 0.94 & 0.81 & 0.72 & 1.04 & 0.91 & 0.80 & 1.12 & 0.97 & 0.86 & 0.91 \\
\hline \multirow[t]{4}{*}{ Mean } & 1.10 & 0.93 & 0.98 & 1.11 & 0.93 & 0.97 & 1.20 & 1.01 & 1.04 & 1.03 \\
\hline & & & & 2000 & 2000 & 2000 & & & & \multirow{3}{*}{ Mean } \\
\hline & & & & $v s$ & $v s$ & $v s$ & & & & \\
\hline & & & & 1997 & 1994 & 1991 & & & & \\
\hline \multicolumn{4}{|l|}{ Food } & 0.97 & 0.95 & $0.63 *$ & & & & 0.85 \\
\hline \multicolumn{4}{|l|}{ Women's clothing } & 0.97 & 0.86 & $0.54 * *$ & & & & 0.79 \\
\hline \multicolumn{4}{|l|}{ Men's clothing } & 1.50 & 0.97 & 1.00 & & & & 1.16 \\
\hline \multicolumn{4}{|l|}{ Rent } & 1.08 & $0.64 *$ & 0.67 & & & & 0.80 \\
\hline \multicolumn{4}{|l|}{ Household appliances } & 1.33 & 0.86 & 1.23 & & & & 1.14 \\
\hline \multicolumn{4}{|l|}{ Automobile } & $0.60 *$ & 0.70 & $0.47 * *$ & & & & 0.59 \\
\hline \multicolumn{4}{|l|}{ Public transport } & 0.91 & 0.94 & 1.33 & & & & 1.06 \\
\hline \multicolumn{4}{|l|}{ Taxi ride } & 1.10 & 1.22 & $1.61 *$ & & & & 1.31 \\
\hline \multicolumn{4}{|l|}{ Automobile service } & 1.16 & 0.86 & 0.72 & & & & 0.91 \\
\hline \multicolumn{4}{|l|}{ Restaurant meal } & 1.22 & 1.09 & $0.43 * *$ & & & & 0.91 \\
\hline \multicolumn{4}{|l|}{ Hotel stay } & 1.34 & 0.97 & 0.68 & & & & 1.00 \\
\hline \multicolumn{4}{|c|}{ Basket of services } & 1.08 & 1.12 & 0.86 & & & & 1.02 \\
\hline \multicolumn{4}{|l|}{ Basket of goods and services } & 1.45 & 1.12 & 0.66 & & & & 1.07 \\
\hline \multicolumn{4}{|l|}{ Mean } & 1.13 & 0.95 & 0.83 & & & & 0.97 \\
\hline
\end{tabular}

Table 3. Before-After Comparison of Standard Deviations

Notes: Each entry in the table is the ratio of the two standard deviations indicated in the column header. For the UBS series the number of comparisons is restricted by the low sampling frequency. The asterisks indicate whether $F$-tests for the equality of each pair of variances reveal a statistically significant difference. ${ }^{*}$ denotes rejection at the $10 \%$ and ${ }^{* *}$ at the five percent significance level. 


\begin{tabular}{|c|c|c|c|c|c|c|c|}
\hline & \multicolumn{3}{|c|}{ Relative to other EU countries } & \multicolumn{3}{|c|}{ Relative to other OECD countries } & \multirow[b]{2}{*}{ Mean } \\
\hline & 2001 & 2000 & 1999 & 2001 & 2000 & 1999 & \\
\hline Big Mac & 0.84 & 1.50 & 0.89 & $0.48 * *$ & $0.40 * *$ & $0.38 * *$ & 0.75 \\
\hline The Economist & $0.24 * *$ & $0.21 * *$ & $0.33 * *$ & $0.21 * *$ & $0.24 * *$ & $0.37 * *$ & 0.27 \\
\hline Audi A4 & $0.17 * *$ & 0.36 & $0.27 *$ & & & & 0.27 \\
\hline Ford Fiesta & 0.40 & 0.80 & 0.88 & & & & 0.70 \\
\hline Ford Focus (Escort) & 0.46 & 0.44 & 0.56 & & & & 0.49 \\
\hline Ford Mondeo & 0.46 & $6.03 * *$ & 0.46 & & & & 2.31 \\
\hline Mercedes S-Class & $0.15 * *$ & 0.51 & 0.35 & & & & 0.34 \\
\hline Opel Corsa & 1.02 & 0.43 & $37.88 * *$ & & & & 13.11 \\
\hline Opel Astra & 0.52 & 0.42 & 0.58 & & & & 0.51 \\
\hline Opel Vectra & 1.27 & 1.32 & 0.87 & & & & 1.15 \\
\hline Opel Omega & 0.38 & $0.29 *$ & 0.33 & & & & 0.33 \\
\hline Peugeot 306 (307) & $0.23 *$ & $0.27 *$ & $0.32 *$ & & & & 0.27 \\
\hline Renault Laguna & $0.23 *$ & $0.30 *$ & 0.69 & & & & 0.41 \\
\hline Seat Ibiza & 1.18 & $4.37 * *$ & 0.77 & & & & 2.11 \\
\hline Seat Toledo & 0.38 & $0.27 *$ & 0.37 & & & & 0.34 \\
\hline Toyota Avensis (Carina) & 0.66 & 1.19 & 0.62 & & & & 0.82 \\
\hline VW Golf & 0.65 & 1.55 & 0.36 & & & & 0.85 \\
\hline VW Passat & 1.31 & $2.69 * *$ & 0.46 & & & & 1.49 \\
\hline Volvo S40 (440) & $2.70 * *$ & $8.00 * *$ & $0.32 *$ & & & & 3.67 \\
\hline Mean & 0.70 & 1.63 & 2.49 & 0.35 & 0.32 & 0.38 & 1.59 \\
\hline Food & & $0.50 * *$ & & & $0.48 * *$ & & 0.49 \\
\hline Women's clothing & & 0.63 & & & $0.42 * *$ & & 0.52 \\
\hline Men's clothing & & 1.23 & & & 0.85 & & 1.04 \\
\hline Rent & & $2.59 * *$ & & & 0.76 & & 1.68 \\
\hline Household appliances & & $0.31 * *$ & & & $0.33 * *$ & & 0.32 \\
\hline Automobile & & 0.99 & & & 0.97 & & 0.98 \\
\hline Public transport & & 0.63 & & & 0.96 & & 0.79 \\
\hline Taxi ride & & 0.91 & & & 1.05 & & 0.98 \\
\hline Automobile service & & 0.85 & & & 1.01 & & 0.93 \\
\hline Restaurant meal & & 1.05 & & & 0.71 & & 0.88 \\
\hline Hotel stay & & 0.66 & & & $0.64 *$ & & 0.65 \\
\hline Basket of services & & 0.83 & & & 0.90 & & 0.86 \\
\hline Basket of goods and services & & $0.58 *$ & & & 0.80 & & 0.69 \\
\hline Mean & & 0.90 & & & 0.76 & & 0.83 \\
\hline
\end{tabular}

Table 4. Cross-Sectional Comparison of Standard Deviations

Notes: See Table 3. 


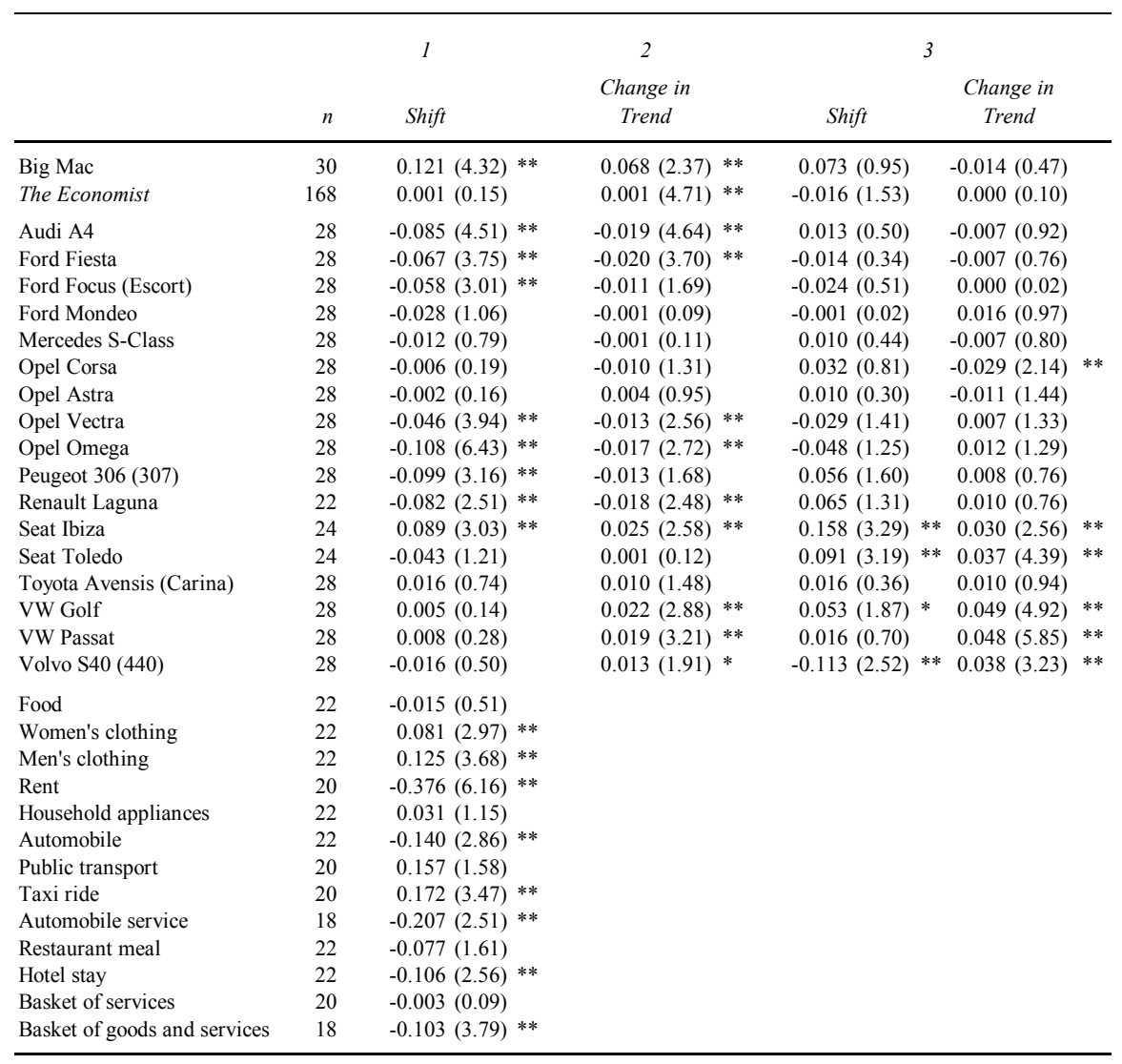

Table 5. Difference-in-Differences Estimates (vs. EU countries)

Notes: The estimates are based on equation (5) in the text. $t$-ratios are shown in parentheses. In column ' 1 ' the DD estimate relates to differences in the level of price dispersion, in column '2' to differences in its trend, and column ' 3 ' allows for both. Only the estimates of the single currency effect are reported in the table. The asterisks denote whether the estimated coefficient is significantly different from zero at the ten $(*)$ or five $\left.{ }^{* *}\right)$ percent significance level. Summary results are provided in Table 9. 


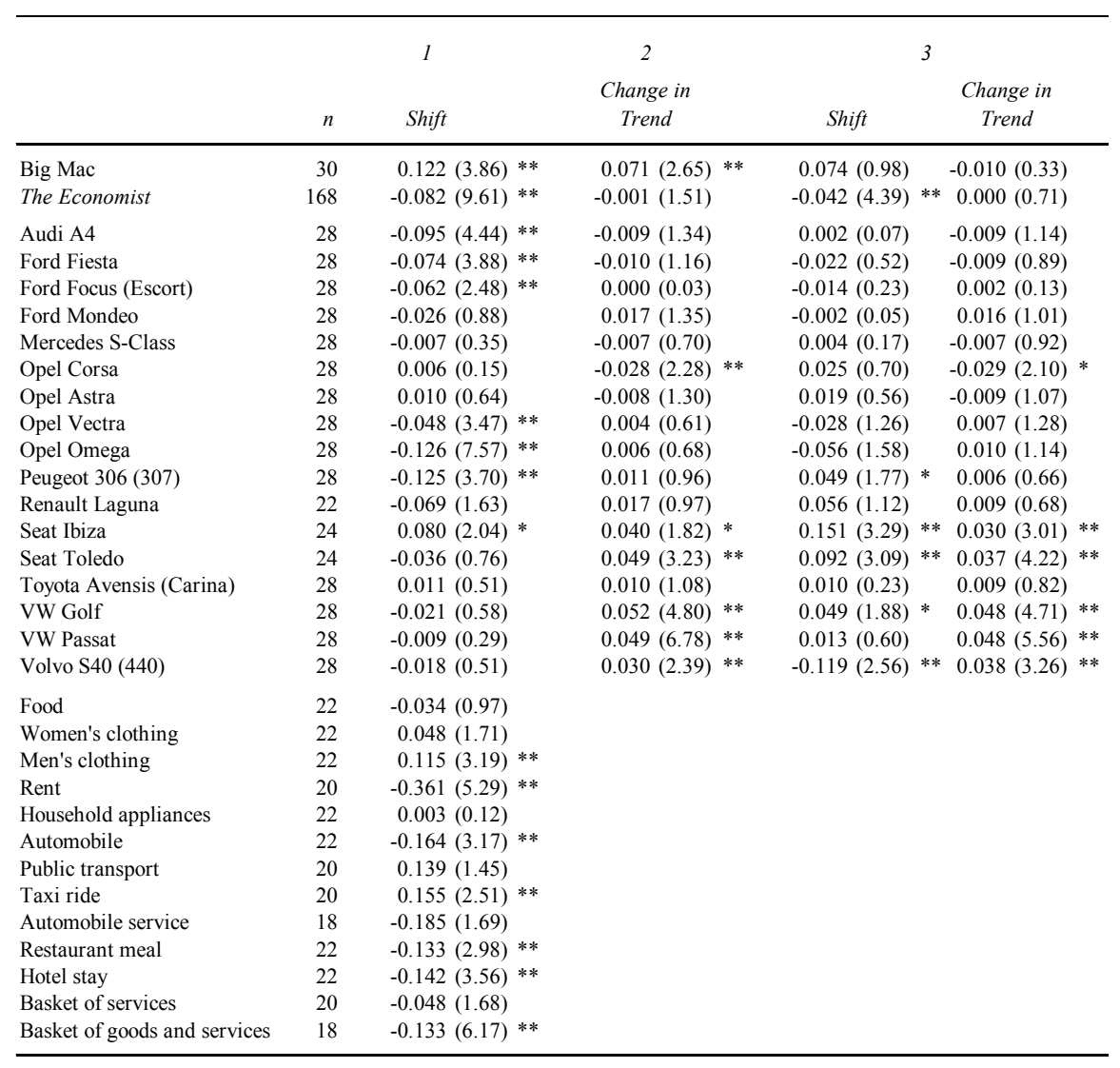

Table 6. Difference-in-Differences Estimates (vs. EU countries, with controls) Notes: See Table 5. 


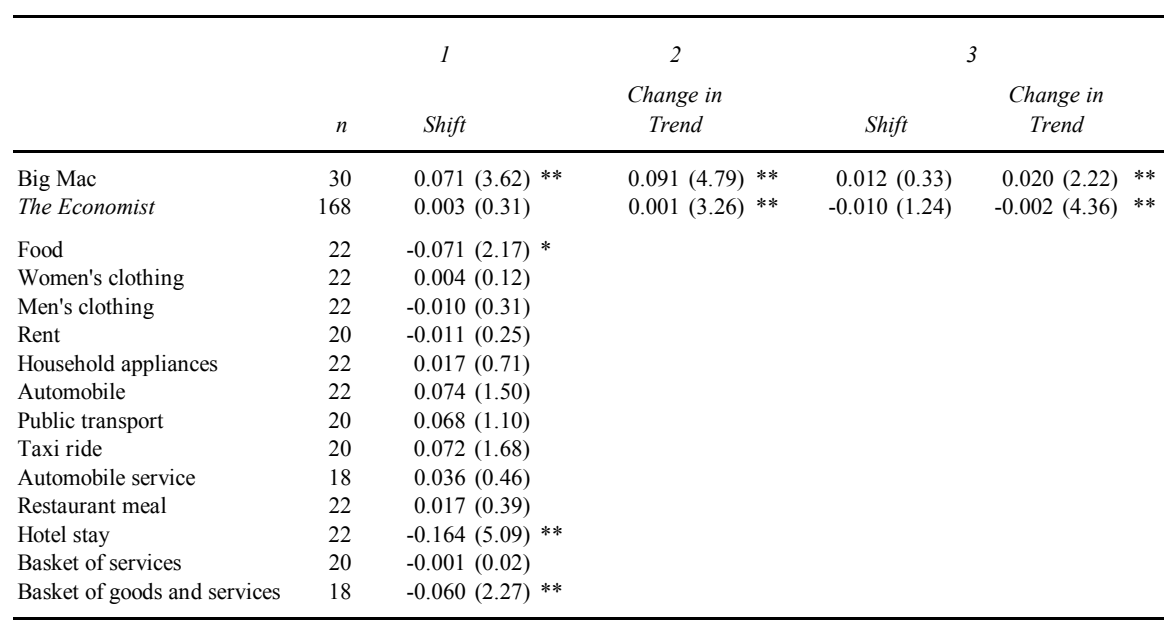

Table 7. Difference-in-Differences Estimates (vs. OECD countries)

Notes: See Table 5. 


\begin{tabular}{|c|c|c|c|c|c|c|}
\hline & $n$ & $\begin{array}{c}1 \\
\text { Shift }\end{array}$ & $\begin{array}{c}2 \\
\text { Change in } \\
\text { Trend }\end{array}$ & Shift & $\begin{array}{c}\text { Change in } \\
\text { Trend }\end{array}$ & \\
\hline Big Mac & 30 & $0.084(3.95) * *$ & $0.101(3.40) * *$ & $0.012(0.36)$ & $0.026(2.43)$ & $* *$ \\
\hline The Economist & 168 & $-0.031(3.07) * *$ & $0.000(0.30)$ & $-0.030(3.80)$ & $* *-0.001(3.70)$ & $* *$ \\
\hline Food & 22 & $-0.071(1.80) *$ & & & & \\
\hline Women's clothing & 22 & $0.023(0.48)$ & & & & \\
\hline Men's clothing & 22 & $-0.003(0.05)$ & & & & \\
\hline Rent & 20 & $-0.001(0.01)$ & & & & \\
\hline Household appliances & 22 & $-0.002(0.07)$ & & & & \\
\hline Automobile & 22 & $0.065(1.01)$ & & & & \\
\hline Public transport & 20 & $0.076(1.20)$ & & & & \\
\hline Taxi ride & 20 & $0.080(1.84) *$ & & & & \\
\hline Automobile service & 18 & $-0.030(0.33)$ & & & & \\
\hline Restaurant meal & 22 & $-0.027(0.48)$ & & & & \\
\hline Hotel stay & 22 & $-0.161(6.11) * *$ & & & & \\
\hline Basket of services & 20 & $-0.029(1.18)$ & & & & \\
\hline Basket of goods and services & 18 & $-0.061(1.58)$ & & & & \\
\hline
\end{tabular}

Table 8. Difference-in-Differences Estimates (vs. OECD countries, with controls)

Notes: See Table 5. 


\begin{tabular}{|c|c|c|c|c|c|c|c|c|}
\hline & & \multirow[b]{2}{*}{$\begin{array}{l}\text { Before-after } \\
\text { comparison }\end{array}$} & \multicolumn{6}{|c|}{ Difference-in-Differences Estimates } \\
\hline & & & $\begin{array}{l}\text { Cross-section } \\
\text { comparisons }\end{array}$ & vs. $E U$ & $\begin{array}{l}\text { vs. EU, } \\
\text { with } \\
\text { controls }\end{array}$ & vs. $O E C D$ & $\begin{array}{l}\text { vs. OECD, } \\
\text { with } \\
\text { controls }\end{array}$ & Total \\
\hline \multirow[t]{4}{*}{ Big Mac } & Total & 9 & 6 & 4 & 4 & 4 & 4 & 31 \\
\hline & signif. smaller & 0 & 3 & 0 & 0 & 0 & 0 & 3 \\
\hline & signif. larger & 0 & 0 & 2 & 2 & 3 & 3 & 10 \\
\hline & net $\%$ & $0.0 \%$ & $50.0 \%$ & $-50.0 \%$ & $-50.0 \%$ & $-75.0 \%$ & $-75.0 \%$ & $-22.6 \%$ \\
\hline \multirow[t]{4}{*}{ The Economist } & Total & 9 & 6 & 4 & 4 & 4 & 4 & 31 \\
\hline & signif. smaller & 9 & 6 & 0 & 2 & 1 & 3 & 21 \\
\hline & signif. larger & 0 & 0 & 1 & 0 & 1 & 0 & 2 \\
\hline & net $\%$ & $100.0 \%$ & $100.0 \%$ & $-25.0 \%$ & $50.0 \%$ & $0.0 \%$ & $75.0 \%$ & $61.3 \%$ \\
\hline \multirow[t]{4}{*}{ Cars } & Total & 153 & 51 & 68 & 68 & & & 340 \\
\hline & signif. smaller & 17 & 11 & 14 & 9 & & & 51 \\
\hline & signif. larger & 11 & 6 & 12 & 15 & & & 44 \\
\hline & net $\%$ & $3.9 \%$ & $9.8 \%$ & $2.9 \%$ & $-8.8 \%$ & & & $2.1 \%$ \\
\hline \multirow[t]{4}{*}{$U B S$} & Total & 39 & 26 & 13 & 13 & 13 & 13 & 117 \\
\hline & signif. smaller & 6 & 7 & 5 & 5 & 3 & 2 & 28 \\
\hline & signif. larger & 1 & 1 & 3 & 2 & 0 & 1 & 8 \\
\hline & net $\%$ & $12.8 \%$ & $23.1 \%$ & $15.4 \%$ & $23.1 \%$ & $23.1 \%$ & $7.7 \%$ & $17.1 \%$ \\
\hline \multirow[t]{4}{*}{ Total } & Total & 210 & 89 & 89 & 89 & 21 & 21 & 519 \\
\hline & signif. smaller & 32 & 27 & 19 & 16 & 4 & 5 & 103 \\
\hline & signif. larger & 12 & 7 & 18 & 19 & 4 & 4 & 64 \\
\hline & net $\%$ & $9.5 \%$ & $22.5 \%$ & $1.1 \%$ & $-3.4 \%$ & $0.0 \%$ & $4.8 \%$ & $7.5 \%$ \\
\hline
\end{tabular}

Table 9. Summary of Results

Notes: The first thee rows for each dataset report (i) the total number of tests, (ii) the number of tests resulting in a significantly smaller degree of price dispersion and (iii) the number of tests resulting in a significantly larger degree of price dispersion (at a ten percent significance level). The row labeled 'net \%' is the difference between (ii) and (iii) expressed as a percentage of (i), for each test category and dataset 